${ }^{1}$ Morgan MY, Jakobovits AW, James IM, Sherlock S. Successful use of bromocriptine in the treatment of chronic hepatic encephalopathy. Gastroenterology 1980;78:663-70.

2 Padfield PH, Morton JJ. Application of a sensitive radio-immunoassay for plasma arginine vasopressin to pathological conditions in man. Clin Sci Mol Med 1974;47:16-7p.

${ }^{3}$ Robinson BG, Clifton-Bligh P, Posen S, Morris BJ. The effect of bromocriptine on circulating vasopressin. Clin Sci 1982;63:367-72.

- Adam WR. Aldosterone and dopamine receptors in the kidney: sites for pharmacologic manipulation of renal function. Kidney Int 1980;18: 623-35.

${ }^{5}$ Horrobin DF. Prolactin as a regulator of fluid and electrolyte metabolism in mammals. Fed Proc 1980;39:2567-70.

(Accepted 3 September 1982)

Department of Medicine, Royal Free Hospital, London NW3 2PF ALEX W MARSHALL, FRACP, research fellow

ANDREW W JAKOBOVITS, FRACP, research fellow (present address:

Alfred Hospital, Melbourne, Australia)

MARSHA Y MORGAN, MRCP, lecturer in medicine

\section{Normal pregnancy in renal transplant recipient with history of eclampsia and intrauterine death}

The only case of eclampsia in a renal transplant recipient was reported in 1979 from this unit. ${ }^{1}$ The patient's subsequent pregnancy was not complicated by hypertension and had a normal outcome, as is reported here.

\section{Case report}

The patient originally presented in 1973, aged 14 years, with hypertension and the nephrotic syndrome due to mesangiocapillary glomerulonephritis. In 1977 she received a cadaveric renal transplant (with no HLA antigens in common) that functioned well after three rejection episodes.

In 1979 she presented at the antenatal clinic with a 20 -week pregnancy. She was normotensive, and the pregnancy progressed uneventfully until 30 weeks, when she developed an acute fulminating hypertensive illness (blood pressure $170 / 130 \mathrm{~mm} \mathrm{Hg}$, proteinuria $1 \mathrm{~g} / 24 \mathrm{~h}$ ) resulting in eclampsia and intrauterine death. She was treated with diazepam and hydralazine. She was delivered vaginally of a female stillborn infant weighing $2193 \mathrm{~g}$ after induction of labour with prostaglandin $\mathrm{E}_{2}$. Recovery was uneventful, her blood pressure settled to $140 / 90 \mathrm{~mm} \mathrm{Hg}$, and the proteinuria diminished. The figure shows renal function after transplantation.
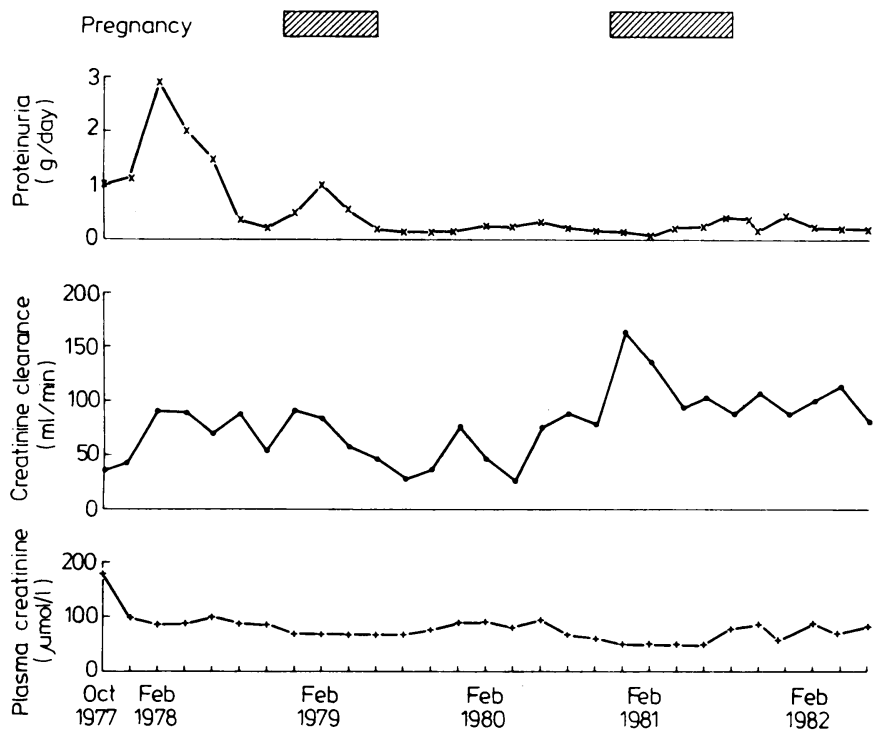

Serial measurements of plasma creatinine concentration, creatinine clearance, and urine protein excretion after transplantation.

Conversion: SI to traditional units-Plasma creatinine: $1 \mu \mathrm{mol} / 1 \approx 0.01$ $\mathrm{mg} / 100 \mathrm{ml}$.
The patient was advised against further pregnancies but conceived again 17 months later, accepted the risks to her kidney, and continued with the pregnancy, which progressed without complication. Clear liquor drained spontaneously at 37 weeks and was followed by a low forceps delivery of a healthy female infant weighing $3530 \mathrm{~g}$. Renal function remained unimpaired during and after pregnancy, blood pressure did not exceed $145 / 90 \mathrm{~mm} \mathrm{Hg}$, and proteinuria remained less than $0.25 \mathrm{~g} /$ day.

Drug treatment consisted of immunosuppression with prednisolone 12.5 $\mathrm{mg}$ and azathioprine $150 \mathrm{mg}$ daily. Antihypertensive treatment comprised propranolol $160 \mathrm{mg}$, hydralazine $50 \mathrm{mg}$, and bendrofluazide $5 \mathrm{mg}$ daily at the time of the first pregnancy and labetolol $300 \mathrm{mg}$ and hydralazine $50 \mathrm{mg}$ daily at the time of the second pregnancy.

\section{Comment}

The occurrence and course of hypertension in pregnancy are unpredictable, and this case exemplifies the difficulty in advising patients about the risks. Incorrect advice had initially been given to this patient. In retrospect, the hypertensive illness in the first pregnancy was classical toxaemia of pregnancy and not complicated renal hypertension, which would be expected to recur in subsequent pregnancies.

The risks of damage to the renal transplant associated with pregnancy are well documented. ${ }^{2} 3$ Some patients, however, are willing to accept these in the hope of a successful outcome. Eclampsia in the first pregnancy need not be a contraindication to further pregnancies in renal transplant recipients, even in the presence of mild hypertension.

${ }^{1}$ Williams PF, Jelen I. Eclampsia in a patient who had had a renal transplant. Br Med F 1979;ii : 972 .

${ }^{2}$ Registration Committee of the European Dialysis and Transplantation Association. Successful pregnancies in women treated by dialysis and kidney transplantation. Br f Obstet Gynaecol 1980;87:839-45.

${ }^{3}$ Williams PF, Jelen I, Anderton JL. Renal transplantation and pregnancy. Dialysis and Transplantation (in press).

(Accepted 24 August 1982)

Western General Hospital, Edinburgh EH4 2XU

P F WILLIAMS, BMBCH, MRCP, registrar in general medicine and nephrology

$M$ JOHNSTONE, MRCOG, senior registrar in obstetrics and gynaecology

\section{Exercise testing in assessment of hypertension}

Recently Millar-Craig et al claimed that maximal and submaximal exercise measurements of blood pressure may provide a better estimate than casual resting values of blood pressure outside the clinic. $^{1}$ We carried out a study of blood-pressure response to exercise testing to define a normotensive and a hypertensive response pattern.

\section{Patients, methods, and results}

We studied 28 normotensive volunteers aged $35 \pm 2$ years and 35 patients with untreated hypertension aged $42+1$ years. Hypertension was diagnosed when diastolic blood pressure was $\geqslant 95 \mathrm{~mm} \mathrm{Hg}$ on three consecutive occasions. A standard ergometric exercise test was performed, the work load being increased at three-minute intervals from $3000 \mathrm{~N} \mathrm{~m} \mathrm{(300} \mathrm{kp} \mathrm{m)} \mathrm{to}$ $4500 \mathrm{~N} \mathrm{~m}(450 \mathrm{kp} \mathrm{m})$ and finally $6000 \mathrm{~N} \mathrm{~m}(600 \mathrm{kp} \mathrm{m})$. Blood pressure and pulse were measured at the end of each interval. On conclusion the exercise was stopped abruptly and blood pressure and pulse recorded after one and five minutes' rest. Results are expressed as means \pm SE. Statistical analyses were performed with the one-tailed $t$ test.

The data obtained in the normotensive group were used to construct a "one-tailed" nomogram. At every point of the exercise testing mean systolic blood pressure and diastolic blood pressure $+1 \cdot 65 \mathrm{SD}$ were plotted (figure). A normotensive response to exercise was defined as diastolic blood pressure $<90 \mathrm{~mm} \mathrm{Hg}$ at the baseline reading and at a work load of $6000 \mathrm{~N} \mathrm{~m}$; a hypertensive response was defined as diastolic blood pressure $\geqslant 95 \mathrm{~mm} \mathrm{Hg}$ at the baseline reading and $>95 \mathrm{~mm} \mathrm{Hg}$ at a work load of $6000 \mathrm{~N} \mathrm{~m}$ (figure).

Systolic blood pressure in the normotensive subjects was $116 \pm 4 \mathrm{~mm} \mathrm{Hg}$ before exercise, rising to $168+4 \mathrm{~mm} \mathrm{Hg}$ at $6000 \mathrm{~N} \mathrm{~m}$. Diastolic pressure was $77+1 \mathrm{~mm} \mathrm{Hg}$ initially and remained virtually unchanged; after one and five minutes' rest it was $66 \pm 2$ and $69 \pm 2 \mathrm{~mm} \mathrm{Hg}$ respectively. In the 